\title{
MOBILE CORPORATE GOVERNANCE: A MODEL PROPOSAL FOR MODERN CORPORATE GOVERNANCE AND INVESTOR RELATIONS
}

\author{
YAKUP ERGINCAN* \\ Central Registry Agency Inc.
}

\begin{abstract}
Mobile Corporate Governance is the process of permanent communication and information sharing between companies and shareholders through the internet, electronic communication and mobile applications to meet the requirements of the principles of corporate governance more rapidly and efficiently and without physical limitations. It provides broadly based and direct participation of the shareholders in corporate management and decision-making processes of the corporation which leads to a higher degree of corporate democracy. It is envisaged that our Mobile Corporate Governance proposal might be a model for other central securities depositories with direct holding systems which have the up-to-date shareholder information. In case our proposal is implemented, the progress of the OECD's main principles of corporate governance will be rapidly enhanced.
\end{abstract}

Key words: mobile corporate governance, OECD Principles of Corporate Governance, dematerialization, central securities depository, CRA, corporate governance, investor relations, corporate democracy, shareholder activism, electronic (virtual) general assembly meeting, electronic voting, shareholder benefits.

\section{MOBILL KURUMSAL YÖNETIM: BİLGİ ÇAĞINDA KURUMSAL YÖNETIM VE YATIRIMCI İLIŞKİLERİ İÇİN BİR MODEL ÖNERİSI}

\begin{abstract}
ÖZET
Mobil Kurumsal Yönetim, şirket ile ortağı arasında kurulan internet, elektronik iletişim uygulamaları ve mobil uygulama tabanlı iletişim ve bilgi paylaşımı sayesinde, fiziksel sinırlamalar olmaksızın, kurumsal yönetim ilkelerinin gereklerinin daha hizlı ve etkin bir şekilde yerine getirilmesini sağlayan ve ortakların şirket yönetimine geniş tabanlı katılımı ve şirketin karar alma süreçlerine daha fazla ve doğrudan katılımını öngören şirket demokrasisinin en üst düzeyde sağlandı̆̆ teknolojik altyapının ortaya çıkardığı sürecin genel adıdır. Mobil Kurumsal Yönetim Platformu önerimizin, hak sahibi bazında kaydileştirme uygulaması yapan ve şirketlerin ortaklarına ilişkin güncel bilgileri tutan dünyanın diğer merkezi saklama kuruluşları için bir model olabilece ği öngörülmektedir. Önerimizin uygulanması halinde, OECD’nin kurumsal yönetim ilkelerinin gelişiminin hızlanacağı düşünülmektedir.
\end{abstract}

Anahtar kelimeler: mobil kurumsal yönetim, OECD Kurumsal Yönetim Illkeleri, kaydi sistem, merkezi saklama kuruluşu, MKK, kurumsal yönetim, yatırımcı ilişkileri, şirket demokrasisi, hissedar aktivizmi, elektronik genel kurul, elektronik oy, ortaklara firsatlar.

* Yakup Ergincan is an Associate Professor and the CEO of Central Registry Agency Inc., Askerocağ $\breve{1}_{\text {Caddesi, }}$ No:1-15, Şişli, Istanbul, Turkey. E-mail: yakup.ergincan@mkk.com.tr

Boğaziçi Journal Vol. 25, no. 1(2011), pp. 171-200. 
Efficient management of a joint stock company, an essential element of the modern economy, is very important. The management of a company carries out duties that determine the decision-making processes during specific financial and economic situations. Thus, it is expected that the quality of corporate governance can affect the results of the economic activities of companies positively, and that these results will be reflected in the stock prices in case the conditions of an effective market are provided. Accordingly, corporate governance is mainly known as an approach related to how companies are managed in terms of their own economic performances and of the effective allocation of the resources in the economy (Clark, 2000).

The main purpose of this study is to make suggestions that would contribute to the progress of corporate governance in Turkey. These fall under the following four points: 1) It is to identify the corporate governance related innovations as a result of technological developments in order to upgrade the corporate governance levels in Turkey to that of the developed markets; 2 ) to discuss the functions of the Central Registry Agency Inc. (CRA) which would facilitate the corporate governance practices; 3 ) to increase the level of corporate governance as a result of the mission taken with the dematerialization process of capital market instruments; and 4) to suggest and explain the benefits of new technology that would contribute to the corporate governance. This study will demonstrate, determine, and detail the concept of the Mobile Corporate Governance for the first time in the literature. It proposes a model for central securities depositories in other countries by determining the economical benefits and externalities that would result in an infrastructure acting as a technological bridge between companies and shareholders for the development of corporate governance and investor relations.

\section{THEORETICAL FRAMEWORK OF CORPORATE GOVERNANCE}

\section{The Concept of Corporate Governance}

Despite the presence of some studies that demonstrate that corporate governance has been widely practiced in Europe, in USA and in Japan since the $19^{\text {th }}$ century (Morck and Nakamura, 1999), the term corporate governance became used extensively in the 1980s (Shleifer and Vishny, 1994). During the 1990s, corporate governance was placed at the top of the agenda of everyone involved with finance and financial markets including individual and corporate investors, shareholders, and managers.

So what is corporate governance? According to a widely accepted definition developed by Ira Millstein, corporate governance refers to that blend of law, regulation and appropriate voluntary private-sector practices which enable the corporation to attract financial and human capital, perform efficiently, and thereby perpetuate itself by generating long-term economic value for its shareholders, while respecting the interests of stakeholders and the society as a whole. In other words, corporate governance comprises legal, regulatory, and appropriate voluntary private-sector practices which enable a corporation

- to attract financial and human capital,

- to perform efficiently,

- to achieve its goals, and

- to fulfill legal obligations and social expectations. 
Corporate governance is all aspects of the systems and processes that entities should have in order to protect initially the shareholders' interests and then the interests of all the other groups that are directly or indirectly related to the company (Çetiner and Erol, 2007). According to the Corporate Governance Committee of Organization for Economic Cooperation and Development (OECD), corporate governance, in the broadest sense, can be defined as a system in which companies are directed and controlled, and it essentially includes the sequence of relations between the management of the company, the board of directors, shareholders, and other interest groups. Corporate governance reveals the structure in which the objectives of a company are established, and in which the tools to achieve these objectives and to monitor the performance are determined (OECD, 1998).

Corporate governance, without question, is a term associated with the general management and organizational structure of a company. However joint stock companies which became almost identical to the concept of corporate governance in recent years have not had a long history (Hansmann and Kraakman, 2000). The USA and UK play leading roles in the development of corporate governance; legal regulations and reports of these countries comprise the basis of international standards of corporate governance (Bauen and Venturi, 2009).

As described by the managers of the World Bank in their "Corporate Governance-Framework for Implementation" report, a shareholder oriented corporate management model can be considered to be the most appropriate model and the determining factor for national standards for this framework. This is appropriate especially for developing countries as they work to approach these standards.

Corporate Governance Principles (OECD, 1998) were approved on 26-27 May 1999 at the ministerial level at the OECD Council Meeting. The OECD corporate governance principles consist of six parts: i) ensuring an effective corporate governance framework; ii) rights of a shareholder and key ownership functions; iii) equitable treatment of shareholders; $i v)$ the role of stakeholders in corporate governance; v) disclosure and transparency; and vi) responsibilities of the board.

Towards the end of the 1990s, national corporate governance laws, principles and the rules of Germany, Korea, France, Russia and other countries (Capital Market Board of Turkey, 2003) and the origin of national best practice regulations were based on either exact or very similar OECD corporate governance principles.

The Corporate Governance Center prepared a report called "21st Century Governance Principles for U.S. Public Companies." It defined 10 management principles for enterprises. It was intended to improve the understanding of corporate management. These principles were as follows (Asian Pacific Economic Corporation Forum, 2003):

1. Interaction: Sound governance requires effective interaction among the board, management, the external auditor, and the internal auditor.

2. Board Purpose: The board of directors should understand that its purpose is to protect the interests of the corporation's stockholders, while considering the interests of other stakeholders.

3. Board Responsibility: The Board is responsible for the fulfillment of corporate activities in a reliable manner, first against to the shareholders and then to all related parties. The board's major areas of responsibility should be monitoring the CEO, 
overseeing the corporation's strategy, and monitoring risks and the corporation's control system.

4. Independence: Independence is the lack of professional or personal ties between the managers and the corporation or its management. The members of the board and the audit committee should be independent from the corporation's management.

5. Expertise: The managers and board members should possess relevant industry, company, functional area, and governance expertise.

6. Meetings and Information: The board should meet frequently for extended periods of time and should have access to the information and personnel it needs to perform its duties.

7. Leadership: The roles of Chairman and CEO should be separate.

8. Disclosure: Proxy statements and other board communications should reflect board activities and transactions in a transparent and timely manner.

9. Committees: The nomination, compensation, and audit committees of the board should be composed only of independent managers.

10. Internal Audit: All public companies should maintain an effective, fulltime internal audit function that reports directly to the audit committee.

Along with the enhancement of the social pressure and expectations regarding the company practices, the necessity of action by the corporate managers through taking into account of groups which are affected by the activities of the company or which might affect the activities of the company, has become more important (Tuzcu, 2005).

Shareholders are providers of the capital, equity and human resources gathered to produce the profit within the establishment. Financiers are usually rewarded through making the profit because of the capital they provide; however the amount of the profit and its allocation to providers depend on the decisions taken by the managers in their next terms. The role of the responsibility mechanism, burdened by the corporate governance relevant to the company affairs of the managers, is important here (Lloyd-Jones, 2010). In this context, capital providers must be ensured that the profit they expect in consideration of the capital they provide must not be kidnapped by the managers (Mietzner, 2009).

The probability of utilization by the managers from the special benefits of the control of power through misuse of it, such as receiving a high degree of income and fees other than salary, is described as an agency problem (La Porta et al., 1999) by many researchers and implementing institutions in the literature.

Harm (2000), claims that the agency problem combines two important components: i) acquisition of the assets by the managers, in the case of a weak shareholder control, and ii) the acceptance of the projects that are not going to raise the value of the company but will provide benefits to the managers, in the case that the shareholder control is relatively stronger. The rise in the number of the institutional investors investing in the companies as equity capital or credit is one of the most important factors to have affected the rise in the importance of corporate governance. The common opinion is that a well accepted corporate governance decreases the risk of a company and accordingly the rate of return demanded by the investors (cost of capital of the company). 
In case the investors are not protected and cannot control the company, they may not invest at all. This case may render external finance impossible. However, this case rarely happens even in either underdeveloped or developed countries where the most of shares are dominated by public joint stock companies (Gürbüz and Ergincan, 2004).

A number of expressions have been put forward such as "Investor over-optimism,"(1) "reputation compulsion of the investors,"(2) and "legal protection of investors" in order to expand the definition of this case. Even though reputation concerns or investor over-optimism may be effective, as La Porta and others assert, legal protection of outside investors presents a more effective barrier than the problem that investors who have not provided funds benefit from reputation concerns or investor overoptimism, or from information of other investors who paid funds.

When the rules such as the voting rights of the shareholders and the reorganization and liquidation rights of the creditors are extensive and well enforced by regulators or courts, investors are willing to finance firms. When the rules and their enforcement do not protect investors, corporate governance and external finance policy do not work well (La Porta et al., 1999).

Corporate governance has many characteristics that make it difficult to imitate. Dynamic capabilities are other important elements in acquiring competitive advantages. Even though corporate governance makes important contributions to growth companies, the preferences of the company in the decision making process, and changing necessities may render the sustainability of the competitive advantage of the company questionable (Kleinschmidt, 2007).

Disclosing good corporate governance practices to the persons concerned is as important as having them in the first place. Corporate governance must be one of the goals of the company, must be adopted by all of the workers, and must be acted upon accordance with these principles (Tekinay, 2006).

Good corporate governance must include the elements of discipline, transparency, independency, accountability, responsibility, equality, and social responsibility. If corporate governance is implemented through these elements, the goals of efficiency and productivity will be obtained. The main requirements for an efficient corporate governance are 1) the composition of corporate values and strategic goals in the organizational structure of the company, 2) the comprehension of the importance of the control functions of internal and external audits and the efficient benefit of their work, 3) a clear determination and application of the competence and responsibilities in the company, 4) an appropriate surveillance by the high level managers, 5) a transparent continuation of corporate governance, 6) a provision for the supporting conditions for efficient corporate governance, 7) a good determination and efficient application of competence and 8) the responsibilities of the surveillance and audit authority (Çetiner and Erol, 2007).

For the reason that "innovation" contains ambiguity as a course of its nature, an innovative enterprise has to begin new projects and invest in them without full knowledge of the expected results (Çetiner and Erol, 2007). This case entails the requirement of resources relevant to investment for research and application of the projects that have a characteristic of innovation. Venture capitals become the main fund resource for this type of enterprise through providing control of the governance. The role of corporate governance for these types of companies is to provide confidence for investors and to attract more external finance for preserving the innovation process. 
On the other hand, studies demonstrate that the rise of the performance of listed companies depends on the attention they pay to corporate governance (Brown and Caylor, 2004; Gürbüz and Ergincan, 2004). In a study of Brown and Caylor (2004b) that researched corporate governance and company performance through using detailed corporate governance data provided by a credit rating agency, 51 factors are determined in 8 corporate governance categories. These categories are audit, board of directors, articles of association, director education, executive and director compensation, ownership structure of the company, progressive practices, and a registered office of the company. The output, corporate governance rating is correlated with company performance, value and dividends paid to shareholders. Over 2000 companies are analyzed. According to this study, better governed companies are comparatively more profitable, their values are higher and they pay more dividends to their shareholders. ${ }^{(3)}$

Managers have to maximize the welfare of the company through maximizing the welfare of shareholders. However, through separation of the control and ownership, the differentiated benefits of shareholders and managers may cause a manager to work for his personal goals which are different than company's goals. This case may cause a hazard for the new model because it may impair the benefits of shareholders (Harm, 2000). Shareholders must preserve at least a part of the control of the company including voting power in the strategic decisions, the power of substitution of a manager and surveillance power of the company (Shleifer and Vishny, 1994; La Porta et al., 1999). In such cases, when the direct control ability and power diminishes, indirect control instruments may be used such as the board of directors, audit committee and reward committee. The main justification for a direct control of managers by shareholders is the voting rights of shareholders and the decision power and ability of shareholders in the general assembly meetings.

\section{Voting Rights: Direct Control of Corporate Governance by Shareholders}

The direct control ability of shareholders through voting in the general assembly meetings determines the power balance between shareholders and managers. Voting rights, and relevant to these, rights to control, theoretically must be proportional to rights on assets such as ownership rights. Accordingly, the rule of one share one vote means that shareholders may participate the decision making process in proportion to their ratio of ownership. Due to the infringement of the rule of one share one vote, enhancing the control power of major shareholders over minority shareholders negatively affects the quality of corporate governance. The disproportionality between cash flow and rights to control in governance negatively affects the quality of corporate governance as well.

The structure in which a subsidiary possesses the share of the principle company threatens successful corporate governance. In the determination of the board of directors by managers and the control of board of directors by managers instead of the control of managers by the board of directors, insiders may acquire the majority in the subsidiary owning the shares of the principal company that has this type of structural problems and executing voting rights; hence, probably the sole goal in successful sharing is accomplished by convening a general assembly meeting and appointing a board of directors (Balioğlu, 2000).

On the one hand, shareholders are the main parties bearing the accountability of the board; "voting" is accepted as a way of rendering that account in practice. The democracy regarding shareholders is similar to the political democracy in terms of making and applying decisions relevant to broadly based (enchorial) products and services (Leech, 2002). 
With the direct investment of foreigners in world trade, the necessity of centralization of internationalization strategies becomes more observable. The governance methods of companies, ways to control them, the goals they aim to reach, the rights used, how relevant responsibilities and created values are shared, all come to play an important role not only for the managers and shareholders but also for broader bodies (Clarke, 2007).

The systems composed of both institutions and enterprises have standards and principles acknowledged by everyone. The determination of these establishes the concept of corporate governance. These principles are also called the principles of the corporate governance (Doğu, 2003). The main principles acknowledged in the world are transparency, accountability, responsibility and fairness.

\section{CENTRAL SECURITIES DEPOSITORIES AND CENTRAL REGISTRY AGENCY INC.}

Central Securities Depositories (CSDs) can be categorized based on the securities under their custody and the services they provide. CSDs can be further divided into two basic groups based on custody types. Some CSDs provide electronic book-keeping while others hold securities in physical certificate form, that is, in paper form. Also, some CSDs hold securities in both physical and dematerialized (electronic) form. Electronic book-keeping is a relatively new concept and in recent years CSDs are moving into dematerializing the securities and into holding the records in electronic rather than in physical form.

CSDs can also be categorized based on types of securities under their custody. Some CSDs may only hold private sector debt instruments while others may only provide depository services for government debt securities. The latter type of CSDs are generally central banks. Some CSDs may hold both types of securities. Categorization between CSDs can also be made depending on depository services of CSDs. There are some basic functions of depository institutions; thus CSDs can be divided into different groups depending on those services. Some basic depository services can be summarized as safekeeping/custody, corporate actions, data services, clearing and settlement, and agency services such as tax services.

Another criterion for categorization is the account structure types of CSDs. There are two types of account holding systems; they are direct (based on beneficiary owner accounts) and indirect accounts (participant omnibus accounts). The former can be defined as retail, whereas the latter are wholesale models.

There are mainly three types of application models in electronic book-keeping systems in the world today. Detailed definitions of those models are below.

Model A: This is used in the USA, Canada, some countries in Europe, South Africa and Hong Kong. In this model, issuers or their agents keep records of registered shareholders in their books including all securities deposited at the CSD. The CSD keeps detailed records of securities ownership on a participant intermediary institutions basis. Participants such as banks and brokerage houses, in turn, keep records of investors' total securities holdings in their systems. 
Model B: In this model registrars keep central depository records for all securities. The CSD holds securities with regard to its participants. In this depository model, individual securities holders (investors) are recorded either under representative participant accounts or directly in their own registered name and accounts. Direct holding models are relatively more costly for CSDs. This means that in every issuer transaction (i.e. dividend and interest distribution, redemption, general assembly meetings) the CSD generally transmits all related shareholder (investor) and participant records to the issuers' transfer agents. Implementation of this model is widely discussed in the UK and South Africa.

Model C: This model, which is also used in Turkey, is a direct holding model overall. Some of the countries in the world using this system are Norway, Greece, Denmark, Finland (partially), Sweden, Switzerland, Australia and New Zealand. In summary, the securities under custody are recorded in the investors' unique ID numbers that are provided by CSDs. In order to be recorded in this system, investors should either have accounts under a participant depository institution or be represented by an intermediary institution. Investors cannot open securities accounts directly with the CSDs in this model (Ergincan, 2005).

As can be seen, depository systems may differ among the countries. However, all countries are moving to dematerialized electronic book-keeping systems irrespective of their depository account holding models. One common application among all countries though is the immobilization of securities certificates in central depositories (Ergincan, 2005).

\section{Dematerialized System and Companies in Turkey}

CRA, the CSD of Turkey, was established according to the amendment made to the Capital Market Law No: 2499 by article No: 10/A of the CML No: 4487. Capital market instruments and rights affixed to them are held in dematerialized form with regard to issuers, intermediary institutions and rights holders in the electronic book-keeping system of CRA. Issuers of capital market instruments (i.e. publicly-traded companies, founders of investment funds, issuers of private sector debt instruments and bank bills) and intermediary institutions, participation banks, derivative instruments brokerage companies and clearing and settlement institutions are participants of CRA. The records in the Central Dematerialized System, the proprietary electronic system of CRA, are registered by the system operator participants. Operational and legal transactions with regard to securities are also conducted by the system participants.

On 28 November 2005, the dematerialization process began for all shares of companies traded on Istanbul Stock Exchange (ISE) on a shareholder basis. By the end of 2010, CRA holds 31.6 million accounts with a total market value of US\$ 331 billion belonging to 17.5 million investors. Of these, 99.99\% of the shares of 347 issuer companies are held in a dematerialized form on CRA's electronic platform. Other than stocks, CRA keeps investment funds participation shares, private sector debt instruments, bank bills, covered warrants and exchange traded funds on a beneficiary owner basis under its custody. Electronic book keeping transactions are not only limited to capital market instruments; they also involve financial and managerial rights such as pre-emptive rights or the rights of usufruct affixed to shares.

Four hundred fifteen issuers of dematerialized securities are linked to the CRA, and 4 million investors can directly access the system by using the web and the mobile communication media ${ }^{(4)}$ to receive 
information on their portfolios. Investor accounts are opened by CRA participants. In order to open investor accounts, investor IDs and contact addresses are received by the participants. In case a real person investor has several securities accounts with different participants, the integration between CRA and the Turkish Identity Information Sharing System (KPS) is used to verify the identity of the investor. Likewise, identities of legal person investors are verified with the integration between CRA and the Turkish Ministry of Finance's Tax ID Number Database. ${ }^{(5)}$ Investor accounts are established quickly; likewise also the uniqueness and accuracy of investor identities are ensured where investors have multiple securities accounts in different institutions by the aforementioned system integrations. Investor identification numbers and passwords are sent by CRA to all investors, thus providing the accuracy and efficiency of the investor services and model suggestions that will be explained later in this paper.

Tekinalp states that the records held by CRA with regard to companies constitute prima facie evidence in assigning the disposing authority (Tekinalp, 2000). In current practice, public joint stock companies do not make any records with regard to bearer shares in their stock ledgers. Even if such records were made, they would not have any meaning in legal terms. From the public joint stock companies' perspective, the main source for the records on bearer shares is CRA. The shareholding records at CRA, either registered or in bearer form, constitute a stock ledger for floating and non-floating shares. Furthermore, those records contain the most up-to-date shareholder information. Companies examine the shareholder records at CRA before general assembly meetings.

In the dematerialized system (established in the aforementioned respect) physical certificates were replaced with the electronic book-keeping records of securities. Consequently, the records of right ownerships that represent the capital of a company are created by the transactions of CRA participants. Besides the right ownership information of all shareholders of a company, CRA records contain other kinds of contact information such as e-mail addresses and mobile phone numbers. Accordingly, stock ledgers and right ownership information on other securities issued can be provided electronically to companies on a real time basis. On the other hand, CRA functions are not restricted to dematerialization of physical shares and electronic safekeeping. The central depository holds all capital market instruments such as private sector debt instruments and investment fund participation certificates in dematerialized form, and the investor rights, and right ownership information on those instruments (Gürbüz and Ergincan, 2004).

Considering the legislation governing the dematerialized system in Turkey, CRA has made important contributions to corporate governance directly or indirectly. For instance, the following issues;

- The decision on taking the records at CRA as basis without the need for further application by any party in registering the transfer of shares at the share registers of companies pursuant to Article 417 of the Turkish Commercial Code,

- Keeping of records on all floating or non-floating shares of a company and rights affixed on those shares on a right owner basis by CRA,

- Shareholders' exercise of rights during the rights issues, bonus issues, and the dividend distributions in the most cost-effective, accurate and timely way,

- Shareholders' ability to transfer their shares to other parties or institutions immediately and effortlessly, 
- Instant delivery of the most up-to-date list of shareholders and shares blockage lists to related companies for the participation of shareholders in general assembly meetings,

- Effortless application of general assembly meeting securities blockages for shareholders,

- CRA's continuous delivery of information to related companies about their shareholders,

can be regarded as legislative functions attributed to CRA that might have possible direct contributions to corporate governance (Gürbüz and Ergincan, 2004). The diagram below summarizes this case:

\section{Diagram 1}

\section{Diagram Outlining the Relation between Issuer's Stock Ledger, CRA and Shareholders}

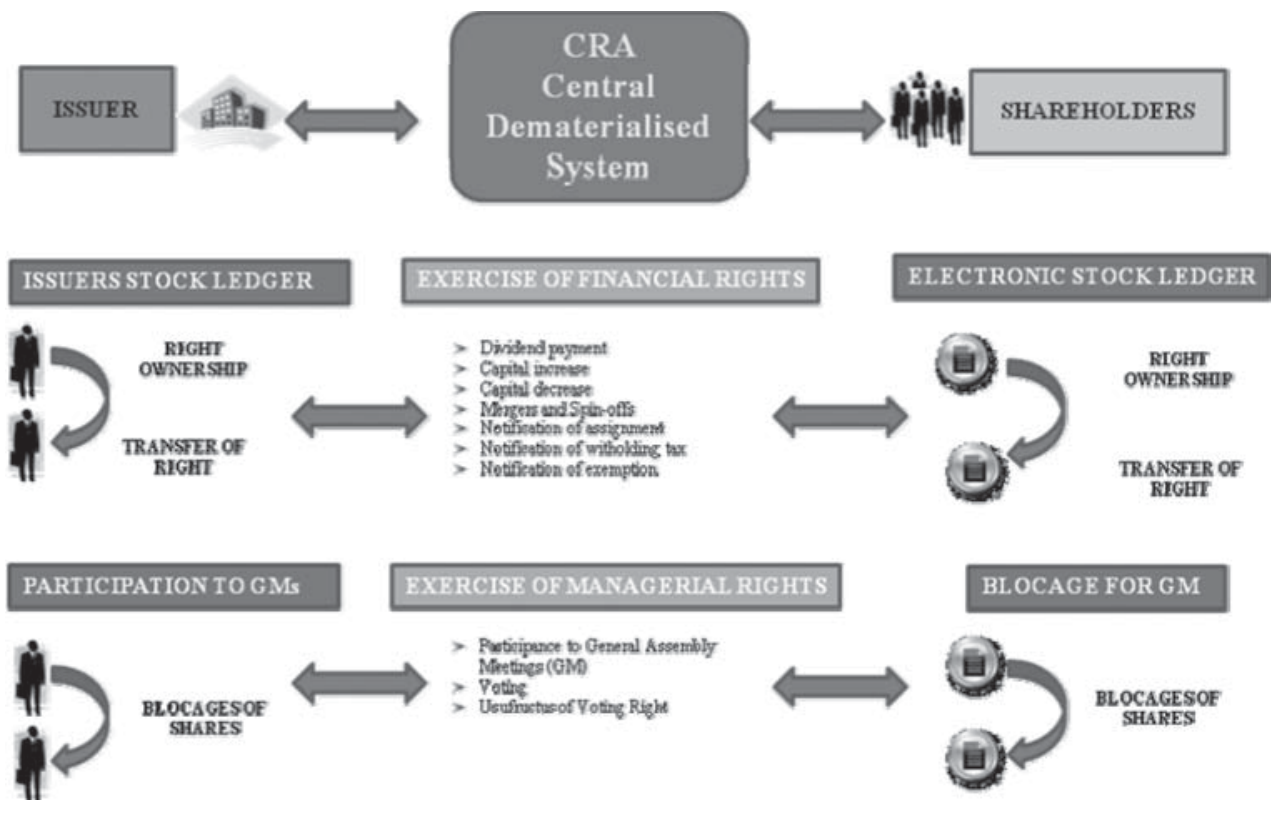

\section{Investor Services}

As stated above, investors can get services that include receipt of information and application of general assembly meeting blockages and investor blockages by using their identification numbers and passwords. Information services for investors concerning their accounts are composed of "automatic delivery of information" that includes immediate transfer of information on transactions, investor portfolio statements and "standard delivery of information."

Investors who want to participate in company general assembly meetings can do so by applying general assembly meeting blockages on their shares. Investors also have the opportunity of applying blockages on their securities to restrict the operations of participant intermediary institutions on those securities. 
Investor services are provided through different platforms such as the internet, Call Center, the Instant Voice Recognition (IVR) System and the mobile applications. The IVR System provides standard information delivery, share blockage for general assembly meetings and securities blockage services to investors. Furthermore, investors can receive standard information on their accounts and apply blockages on their securities through the web by entering their identification numbers and passwords or by using their mobile signatures.

Instant alert messages are sent by e-CAS ${ }^{(6)}$ (Ergincan, 2005b) (Electronic Customer Alert System) to investors through electronic communication applications ${ }^{(7)}$ (SMS or e-mail) in case there is an outflow of securities from investor accounts. In order to register to use this service, real person investors should submit their mobile phone numbers to the system; similarly legal person investors should submit their e-mail addresses. In later stages of the e-CAS project, operations of unregistered investors or those operations that were not confirmed electronically by investors will be blocked. Investors also have the option to receive the same information services on all securities for all types of transactions. Investors can apply and cancel securities blockages for general assembly meetings and other investor securities blockages through SMS. Furthermore, CRA delivers regular monthly information through e-mail to investors (CRAweb Investor Operating Guidebook, 2010).

Thus, CRA can be considered as an information and communication bridge between companies and shareholders. Information security on this bridge is based on the PKI infrastructure and electronic signature in accordance with the Information Security Management System applications. System users of participant institutions can perform transactions by using electronic signatures and investors can receive investor services by using identification numbers and passwords that are sent by CRA or with their mobile signatures.

\section{MOBILE CORPORATE GOVERNANCE}

Mobile Corporate Governance is the process of permanent communication and information sharing between companies and shareholders through the internet, electronic communication and mobile applications. ${ }^{(8)}$ Its purpose is to meet the requirements of the principles of corporate governance more rapidly and efficiently without physical limitations. ${ }^{(9)}$ It provides broadly based and direct participation of the shareholders in corporate management and decision making processes of the corporation, leading to a higher degree of corporate democracy.

Mobile Corporate Governance is the process starting from the real-time transmission of any announcement of a corporation to all of its shareholders wherever they are, through the electronic communication and mobile applications. The process is concluded by providing governance of the corporation on electronic platforms including electronic general assembly meetings through continuously taking advice/approval of its shareholders on specific issues using tools such as electronic voting. ${ }^{(10)}$ The details and implementation stages of the "mobile corporate governance" term, which is introduced in academics for the first time in this study, are interpreted below: ${ }^{(11)}$

When the information sharing process is examined, two main categories appear. The first category is the information sharing through communication channels (e-mail, SMS, chat tools which provide oneto-one information sharing and etc.). In this kind of information sharing process, the information is for individual use; however, it is not suitable for common usage. The second category is the distribution 
of information via platforms (corporate web sites, intranet, portal, etc.). Through this method, while a small group creates the information, a large group may benefit from it (Mcafee, 2006). ${ }^{(12)}$

As is the case in the world, direct communication means between the companies and the shareholders are limited in Turkey. There are generally multiple sources of information. Companies send the same information within different formats to different channels but cannot contact the investors with whom they aim to interact. Within almost every country, the efforts to create a Primary Source of Information and to provide information distribution via a single-source have been insufficient so far. Companies and investors cannot acquire all the information they need. Companies cannot be in contact with all of their shareholders; neither can the shareholders connect with all of the issuers. There is no single standardized method in company-investor relations. Furthermore, companies cannot distribute information to all investors simultaneously. The shared information and those formats are not standardized, nor are formats used in accordance with international standards. In order to reach each other, companies and investors are willing to bear high costs.

The structure of the dematerialization system that is briefly explained above grants vast facilities to make CRA create a modern corporate governance and investor relations platform. Corporate governance insufficiency is one of the main problems of the Turkish capital markets. Beyond being a central securities depository, it is assumed that structuring CRA as a corporate governance and investor relations platform would enhance the social and economic benefits of capital markets in Turkey and would lead to decreasing the average cost of capital for companies. Structuring CRA as a corporate governance and investor relations platform would also help companies increase financing possibilities. Furthermore, it would improve the compliance level of the Turkish capital markets with investment feasibility criteria of domestic and foreign investors (Gürbüz and Ergincan, 2004).

It is very important for economies of scale that the following services, which we suggest be provided by CRA, should be given in a whole and standardized manner within a single place. Updated identity, communication and ownership information related to shareholders are kept by CRA. Furthermore, CRA provides the most suitable technological infrastructure system for the communication between both sides. As a result, it is believed that the services taken on by CRA would contribute to the progress of corporate governance and investor relations in Turkey. In terms of economies of scale, it is not appropriate for each company to give the related services to its shareholders separately. It is also far from efficient because stock exchange transactions change the ownership structure frequently.

On the other hand, CRA monitors current shareholders of each company in a single center. Moreover, CRA also has the infrastructure system through which the correct information could be delivered to the addressee (Gürbüz and Ergincan, 2004). It is believed that the stated suggestions would be a model for other central securities depositories around the world in which direct account holding systems could be implemented and up-to-date shareholders information kept.

When the contemporary internet technology is taken into account, it is believed that the immediate communication among all of the capital markets' participants, members and investors would be provided through CRA's web Portal. In this case, CRA Portal would be the most important component of the Mobile Corporate Governance Platform application of Turkey. Investors could get correct, immediate and reliable information about the companies of which they are either shareholders or fund suppliers. Moreover, companies could contribute to the improvement of corporate governance 
by the electronic general assembly meetings on the Portal. Because an investor could get any kind of information provided via the portal structure on the companies in which he has invested, including publicly disclosed information, the exchange of information and transparency would be at the highest level. Consequently, it is believed that the efficiency and development level of Turkey's capital markets would be increased. In this context, with the dematerialization of all securities, the CRA Portal would become a platform through which millions of domestic and foreign investors would effectively receive service and exchange of information between companies, intermediary institutions and investors. The CRA Portal would be designed to include an English version of any kind of information. As a result, the portal would give service not only to the domestic investors but also to the foreign ones (Gürbüz and Ergincan, 2004).

Instead of getting non-standard sets of information by means of navigating the web sites of companies ${ }^{(13)}$ through achieving standard, immediate and updated information using a single platform investors could make comparisons between companies respecting their corporate governance, investor relations and performance principles. With this, the CRA Portal would be a benchmark regarding the degree to which the companies believe in corporate governance and share information with their shareholders. In a way the CRA Portal would become a corporate governance rating center where companies would be judged by investors in terms of the scope of information and services they offer.

Furthermore, one of the most important features of the Mobile Corporate Governance Platform is to gather companies and shareholders without disclosing the identities of investors unless they wish to do so. Thereby, information security is one of the most important components of the platform.

\section{Components of the Mobile Corporate Governance Platform}

Before evaluating the Mobile Corporate Governance Platform application together with the CRA Portal, which will be at the center of this application, it would be beneficial to mention the Public Disclosure Platform (PDP) and Central Corporate Entity Databank (MERSIS) briefly.

The PDP, which is an electronic data collection and publication system, aims to transmit safely the financial statements, public disclosures of material events and other events of public companies and all of the intermediary institutions (ISE 2010, Public Disclosure Platform). Through the PDP, declared announcements are publicly disclosed immediately and the users can obtain information in a simultaneous, safe and immediate manner from the PDP website. The PDP was launched in June 2009.

The MERSIS system, which was established by the Ministry of Industry and Trade, provides a number of facilities for companies such as the establishment and dissolution of companies and maintenance of documents in the electronic environment. Through the MERSIS, a unique identification number is given to legal persons, for instance companies, charitable foundations, associations, and real person enterprises. This number system facilitates the monitoring of all kinds of activities of legal persons, creation of registry books, keeping of updated, correct and accessible forms of records in electronic environment, designation of sector codes during the foundation process, and determination of industry and trade inventories (entrepreneur information system). In addition to these, with the creation of the database, the correct statistical data required by the Ministry of Industry and Trade and related public bodies and organizations would be ensured immediately (The Ministry of Industry and Trade, 2010). 
After briefly mentioning the PDP and MERSIS, the functions and components of the CRA Portal, which is the corner stone of the Mobile Corporate Governance Platform, are explained below:

Public Disclosure: In brief, on the CRA Portal, corporate governance and investor relations are to be assessed in a new dimension. The CRA Portal is also to be the corner stone of the Mobile Corporate Governance Platform. In addition and with respect to regulations and CRA services, the information flow within the CRA Portal could be composed of the data that are transmitted directly to the Portal by companies, and that are transmitted indirectly by the companies via integration with the PDP and MERSIS (Gürbüz and Ergincan, 2004). As a result of direct and indirect gathering of information and documents within the CRA Portal, the information and document samples that could be received from the Portal are (Gürbüz and Ergincan, 2004):

- Information about the Company, the PDP Announcements and Disclosures,

- Company News and Analysis Reports,

- Financial Statements disclosed on the PDP,

- Accounting and Dividend Policies,

- Direct and Indirect Partnership Relations, Voting Agreements, Number of Shareholders within Groups,

- Articles of Association, Trade Registration Information, Privileges that are taken from companies or the MERSIS,

- Annual Reports, External Audit Reports and Internal Audit Reports,

- Board of Directors' Decisions that could be disclosed to the public and incorporated in the Code of Ethics,

- General Assembly Meeting Information (Date, Place, Agenda, Detailed Dividend Policy including Dividend Distribution Proposals and Reasons, Articles of Association Amendment Text, Proxy Paper Samples, Detailed Information about Members of Management and Audit Bodies, Voting Procedure, Previous Minutes of Meetings and Voting Results, etc.),

- Detailed Capital Increase and Dividend Payment Information/Plan, Prospectus, and Circular,

- Decisions of General Assembly and Board of Directors' Meetings,

- Videos of Previous General Assembly Meetings and Board of Directors' Meetings,

- Videos of Corporate Managers' Speeches, Company Presentation Films.

Consequently, through the CRA Portal, in accordance with the public disclosure and transparency terms that constitute corporate governance principles, the goal to disclose financial and non-financial information on companies to both current and potential shareholders in a timely, correct, clear, interpretable, low cost and accessible manner could be achieved. In such a case, the best service would be given to shareholders to receive and inspect the information.

The CRA Portal would be the information distribution channel of companies. The access to the information provided by the CRA Portal during public disclosure would be easy, immediate and at a low cost. The submission of such information, documents and announcements to shareholders and 
investors through internet and electronic communication applications, direct company-to-investor communication processes could be achieved. Material notifications that are disclosed on the PDP could be sent immediately to investors through electronic communication applications. As a result, when the material notifications about any companies are publicly disclosed on the PDP Portal, no matter where the investors are, they could be informed simultaneously. After the system is integrated with the PDP, not only could the companies be directed to transmit the same kind of information to a single center, but also the information could be taken from this center and disclosed to the whole market. Thereby, in a sense the PDP would become a Primary Source of Information; as a result of the PDP-CRA integration CRA could become an Investor Information Center transmitting the information from the Primary Source of Information to investors via electronic communication applications.

Consequently, through the PDP-CRA integration, information about companies would be accumulated, processed and distributed under the CRA Portal from one single point. ${ }^{(14)}$

Investor Announcements and Corporate Action Notifications: The CRA Portal could be defined as the address of immediate, timely and correct public disclosure. In this context, after the necessary amendments have been realized, in addition to notifications including general assembly meeting notifications and material notifications that companies are bound by law to disclose, companies may inform the shareholders and investors at any time on any issue. ${ }^{(15)}$ Notification could be done via electronic communication applications. ${ }^{(16)}$ Issuers may publish the information that they would like to transmit to shareholders or investors through the CRA Portal and may transmit the notification on CRA via electronic communication applications. As a result, companies' notifications via CRA would provide the simultaneous transmission of the notifications limited to a target group. For example, it is clear that the general assembly agenda or notification of proxy voting is related to only shareholders at the time of notification. However, companies pay high costs to print media for these kinds of notifications. Furthermore, companies disclose notifications to related or unrelated readers without being sure whether these notifications are received by the target group. If the notifications are disclosed directly through CRA, not only would the notification costs decrease, but also the notification would be transmitted simultaneously and only to the related persons.

The same services could be made beneficial for real persons and legal persons who would like to make guiding announcements to shareholders and investors for various goals, first among them those of acquisitions. As a result, opportunity would be provided to make announcements not only for the companies but also for other participants who are interested in best serving corporate governance ${ }^{(17)}$ (Gürbüz and Ergincan, 2004).

At the moment, the first phase of transmission of the PDP announcements to foreign investors is accomplished, and in them the announcements about corporate actions are sent in SWIFT format. It is important that the companies should make corporate actions announcements only to the PDP. With the PDP-CRA integration, delivery of these announcements to institutional foreign investors in SWIFT message format via simultaneous and online electronic communication applications would also become important and, it is believed, it increases the effective functioning. As a result, Turkey would be in a different position respecting the transmission of corporate action information to shareholders correctly and immediately through a single center, a much discussed world issue. The positioning of the PDP as the Primary Source of Information in corporate actions is important because disclosure of the same or similar information to more than one party is not only inefficient, but 
also error prone. On the other hand, if the PDP-CRA integration is achieved, for the first time in the world, corporate actions processes in fully-automated and straight through processing form from the company to the shareholder would be provided. Further steps that are to be taken on this issue would increase the effectiveness of Turkish market. CRA's direct contact capability with the investors is the most important factor of this model proposal.

The following diagram (Diagram 2) summarizes the components of the Mobile Corporate Governance Platform and the transmission of announcements on public disclosure, investor and corporate actions notifications from company to investor.

Diagram 2

Components of Mobile Corporate Governance

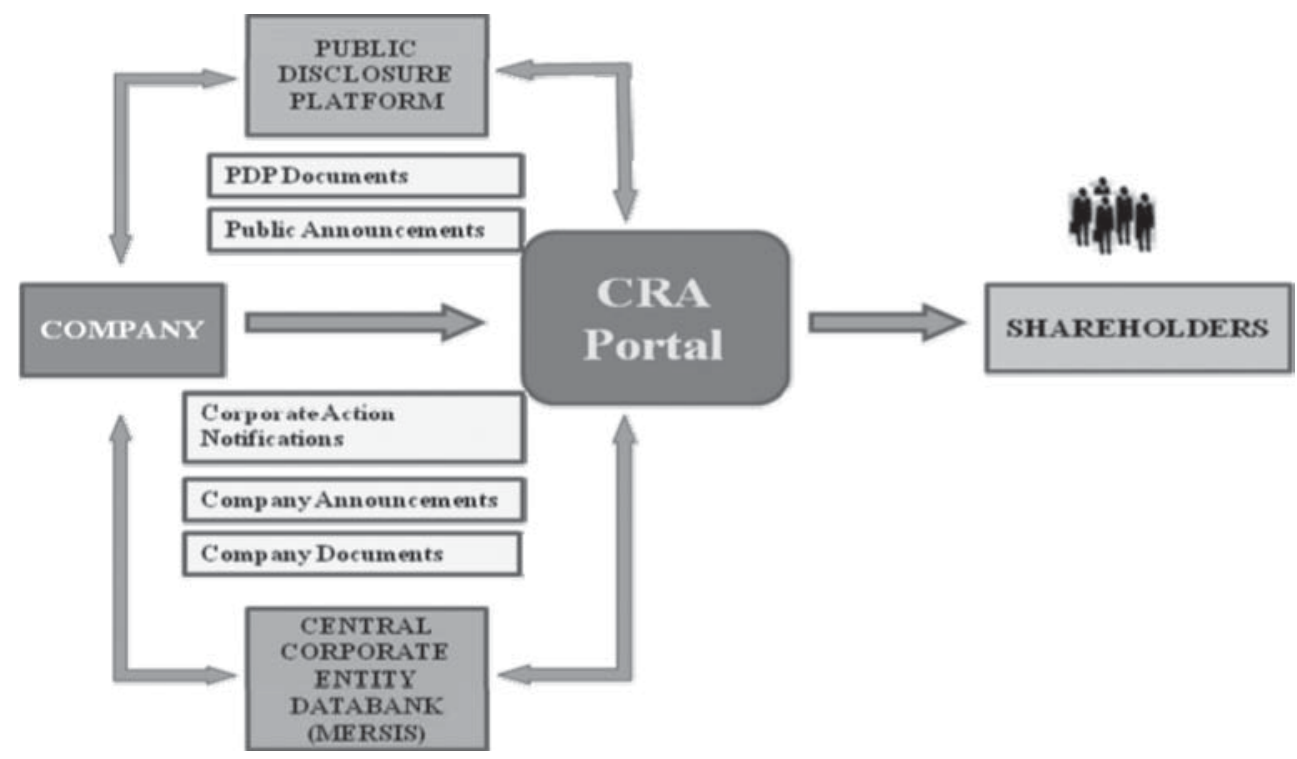

Electronic Assembly and Investor Meetings: The CRA Portal may provide electronic lounges through which shareholders will be able to participate in electronic investor meetings. In the electronic lounges, the shareholders of a company can communicate and engage with each other, and the company authorities can enter these lounges and make informative statements (Gürbüz and Ergincan, 2004). Actually, since the electronic investor meetings will theoretically provide the facility of constituting electronic meetings at any moment for company shareholders, meeting of shareholders and their concurrent cooperation, which is one of the important components of corporate governance, can be made available through the CRA Portal.

Companies can set electronic assembly meetings with a specified agenda for shareholders and potential investors who are identified beforehand. Through the Portal, sharing can be achieved together with both the visual and written presentations held by the company authorities' vision. Shareholders and investors can express their views on the related topics. Consequently, the investor meetings, with their current physical restrictions of reaching the target audience frequently, can be convened whenever requested and in a secure environment through the CRA Portal. 
In this context, an environment through the CRA Portal can be constituted where the companies with the execution of web conferences can communicate by making presentations. In this environment, the participants may share their views, participate in voting, ask questions and get answers.

The infrastructure that is in question can at the same time bring together the board members who wish to have frequent meetings, but who, due to the physical restraints, generally face the difficulty of coming together. Using the CRA Portal, the companies could organize electronic board meetings with the electronic signature infrastructure.

Proxy Voting and Delegated Voting: The proxy system that emerged in the USA regarding proxy voting in the general assembly meeting and has since influenced continental Europe, differs from the traditional voting system through the appointment of a proxy. The most prominent difference between these systems emerges in respect to the occurrence of the intention of the shareholders in the general assembly meeting. In the conventional proxy system, a shareholder may give instructions to the proxy regarding his desires when the proxy is appointed. Nevertheless, even if the shareholder gives instructions, it is possible for the proxy to act contradictory to these instructions. In this case, this act does not affect the validity of the general meeting decisions (Çeker, 1995; Bilge, 2003). However, the aim of the proxy system is to reflect the complete intention of the shareholder in the general assembly meeting. In order to correspond to this aim, the proxy forms including the instructions regarding the voting aspects must be filled out by the shareholder. In these forms the shareholder must write his intention for each article of the agenda. By this form, it is not possible for the proxy to vote contradictory to the preferences recorded on the form (Çeker, 1995).

The waste of time and costs arising due to the delivery of the proxy letters in written document format has been removed through the delivery of these documents via electronic methods. ${ }^{(18)}$ It is possible to designate a dual delivery system for the electronic delivery. First, proxy letters might be sent to shareholders through the web site of the company (Alcock et al., 2006). In this system, the documents pursuant to the appointment of the proxy are displayed on the web site and the information in these documents is sent to the shareholder through the appropriate tools. The shareholders wishing to appoint a proxy can easily receive proxy letters from the web site by downloading those (Freidman, 2002; Brown, 1996). The second approach envisages sending proxy letters to the known e-mail addresses of the shareholders. Sending proxy letters through e-mail would remove the costs and expenses arising from mailing those letters. This allows proxy letters to be sent to shareholders free of charge without waste of time, and with solid evidence on the delivery to the shareholders. ${ }^{(19)}$ On the other hand, the return of the proxy letter forms in the electronic platform is as important as the transmission of those on the electronic platform. When the paper form is sent back to the proxy center, it causes a waste of time and cost. In order to receive an efficient respond from the shareholders regarding the proxy appointment process, it is necessary to ensure that the return of the proxy form to be delivered electronically.

Due to the CRA Portal's technical abilities, which are presented above and can bring a company and its shareholder together whenever required, the proxy process can be performed safely and efficiently. Proxies might be conferred in electronically signed format and the process might be performed through electronic signature from beginning to end. 
In delegated voting systems, shareholders can enjoy their administrative rights through appointing a proxy, since they are not obliged to participate to the general assembly meeting in person. The application of data processing technology is duplicated in the classical appointment of the proxy. First, for the reason that the act of appointing a proxy requires a written and signed proxy letter, the electronic signature technology makes it possible to designate a written proxy letter and appoint a proxy. ${ }^{(20)}$ Secondly, a shareholder who does not participate in the general assembly meeting physically and monitors it through the internet can give instructions to his proxy attending to the meeting during the meeting. When a shareholder appoints a proxy this way, his real intention can be reflected in the decision making process in the general assembly meeting. With a new regulation, the principles regarding real or legal persons can be designated as proxies. This would establish a prerequisite that directors of a company cannot be a delegated voter or be assigned to a voting commission participating in the general assembly meeting. Moreover, the proxies must be able to act solely in accordance with the clear and personal instructions of the shareholders. The instructions derived from the shareholders must be recorded (Bilge, 2003).

With these in mind, it is believed that CRA can undertake a delegated voter function. Another important principle of the corporate governance would emerge safely and accurately through fulfillment of the demands of the shareholders and companies in this aspect because of a secure electronic signature framework on the electronic platform by CRA. In this context, there is no requirement for a comprehensive legislative revision.

Investor Statistics and Polls: One of the important requirements of the companies is to obtain accurate, secure and comprehensive statistics about their shareholders. Through the CRA, which holds the most accurate and updated information on shareholders, any kind of statistical reports can be prepared that meet the company demands. For example, reports intended for showing the time span of equities holding by the shareholders, the demographic and financial features of the shareholders, the sectorspecific preferences of the shareholders, the exchange of equities in shareholder portfolios etc. can be prepared and presented to companies by using the data CRA owns. These types of reports can present important tips and be instructive for companies in terms of investor relations and corporate governance.

On the other hand, companies that wish to learn the views of the present and potential shareholders on a specific issue, through polls on the portal, can reach their shareholders and these shareholders can use CRA to forward their views to the companies. Currently the companies that aim to take the views of their shareholders cannot do this effectively since they cannot know about their shareholders. But CRA, since it is the place where this instant information related to shareholders can be found, can transmit the related polls to the shareholders. Reaching the target group in specifying the potential shareholders can also be achieved through the CRA data. For instance, it would be possible to reach to investors who prefer to invest in a company's specific sector. One of the most important characteristics of this kind of communication method is that it embraces the components of information security. Whereas companies will not know the identity of the investors who answer their polls or information requests, they will be sure to take into account the criteria they specified. As for the investors, they can have the opportunity to communicate with the issuer without disclosing their identities. By conducting polls through the CRA Portal, the results can be transmitted rapidly and assessed by the target group. Thereby, polls can reach their aims safely. 
Moreover, by reaching the existing and potential shareholders, companies can improve their investor relations with the questions and polls they will send to the specified target groups. CRA can be vital in transmitting the questions and polls to the correct address and in compiling and reporting them. For instance, it is very important for today's investor relations to involve the company's shareholders and for the company to send the intended publicity and advertisements messages or to ask and learn the reasons why a shareholder sells the company's share in order to be able to take precautions afterwards to prevent that from happening again.

Furthermore, it will be possible to actualize the system, known as "shareholder benefit," to assure benefits to the persons who become shareholders of a company for a specific time. These benefits are intended to encourage loyalty, and vary from discounts on products to privilege cards. Thus, via CRA Portal, shareholders will easily apply for these benefits. CRA will electronically connect shareholders with companies, and enable them to apply for the benefits through electronic communication and mobile applications. This process will help customers to become shareholders and shareholders to become customers.

Electronic General Assembly Meetings: ${ }^{(21)}$ The best practice for electronic general assembly meetings offers two phases. The first phase is to conduct electronic general assembly meetings before the conventional meeting. Most of the countries have chosen to do so since it is easier and more applicable. In this phase, the duration of electronic meeting is known in advance by the shareholders. They vote during that designated period which is before the conventional general assembly meeting. Once the time is over, electronic votes are collected and reported. Afterwards the conventional meeting is held in which shareholders who voted electronically may not take part. At the end, both electronic and conventional meeting results are collected and reported to finalize the legal procedures.

It is believed that in two ways conducting general assembly meetings on the internet would be beneficial: First, the online participation of some of the shareholders in the general assembly meetingsare made in a conventional way. Second, the conduct of conventional general assembly meetings is completely through the internet. In literature, the former method is called the "online participated presence" general assembly (Kayıhan, 2003) and the latter is called the "virtual general assembly" or the "electronic general assembly."(22)

According to our view, when CRA's vision and the information that it owns is assessed together, in addition to the live broadcasting of general assembly meetings on the internet, it is believed that the shareholders can participate through the internet in general assembly meetings via the CRA Portal, even when the necessary legislation changes have been made. Therefore electronic general assembly meetings will replace the conventional general assembly meetings via the CRA Portal in which electronic voting would be possible (Gürbüz and Ergincan, 2004).

For investors, electronic general assembly meetings need to be understood as participation in the general assembly meetings under the principle of equitable treatment, giving advice or making comments in visual or written/oral forms, sharing advice/views with the other shareholders, voting and doing all the other general assembly and voting services (registering, counting, sharing the results) safely in an electronic environment. For issuers, electronic general meetings are a practical way to keep the registries in regular forms and to transmit the general assembly results to shareholders and relevant parties electronically. In addition to economies of scale that will be brought by providing 
these services from a single center, CRA holds a wide range of information on shareholders from which the CRA participant issuers can benefit directly. Once general assembly meetings could be broadcast live from the internet both in Turkish and in English, this would help shareholders use their rights to participate in the general assembly meetings on equal terms. Since CRA is able to keep the said registries safely and up-to-date, it would be appropriate for these services to be provided from a single point by CRA.

Due to the reasons presented above, it is necessary to provide shareholders access in order to participate in general assembly meetings which will be broadcast live from the internet, and to enable them to use their votes through electronic communication and mobile applications. By this service, which is the continuation of the live broadcasting of general assembly meetings on the internet, shareholders can vote on the topics of the meetings that they will watch live from the internet through the CRA portal. Both by the live broadcasting of the meetings on the internet and the access for using their votes electronically on the internet, shareholders who currently cannot use their rights because of the time and the physical limitations will be able to do so. ${ }^{(23)}$

The dispelling of the costs and the other drawbacks of using written forms of communication in invitations to the general assembly meetings will be offset by issuing invitations in an electronic environment and transmitting them to shareholders. In this framework, it is possible to make the general assembly announcement on the CRA Portal and to give the information and documentation related to the meeting on the CRA Portal. In case the shareholders request proxy from the right owners, the placement of a sample proxy form and the information and documentation related to the proxy request would be provided by the CRA Portal. By using the electronic communication applications, shareholders would be informed that the documentation is on the CRA portal. It is also possible to give the proxy electronically by using electronic signature as stated above. In addition to the cost advantages stemming from invitation, the transmission to the shareholders before the meeting of documentation related to it electronically would also minimize the communication time lapse between the company and the shareholders.

In this framework, the value of using the internet and mobile communication applications is to send the meeting invitations through the CRA portal (to put the invitation to the CRA portal and/or send them by using electronic applications), to make the process of proxy voting and representation in an electronic environment with the electronic signature infrastructure, to enable the shareholders to electronically vote on the topics in the agenda of the general assembly meetings broadcast live through the CRA portal and mobile communication applications, to enable them to interactively participate in the electronic general assembly meetings by using electronic communication and mobile applications and to allow them to transmit their views and decisions through the CRA portal. It is believed that when this process is enabled through the CRA portal, the concept of Mobile Corporate Governance and its effects will be discussed and the Turkish model will impact both corporate governance and the new definition of central securities depository institutions in the world. ${ }^{(24)}$ This infrastructure will also help companies and shareholders have electronic assembly and investor meetings frequently on any subject whenever they want. This will lead to more participation by shareholders in company management.

In the framework of the above offerings, the scheme which summarizes the main points of the Mobile Corporate Governance Turkey practice is presented below: 


\section{Diagram 3}

Mobile Corporate Governance

\section{MOBILE CORPORATE GOVERNANCE}
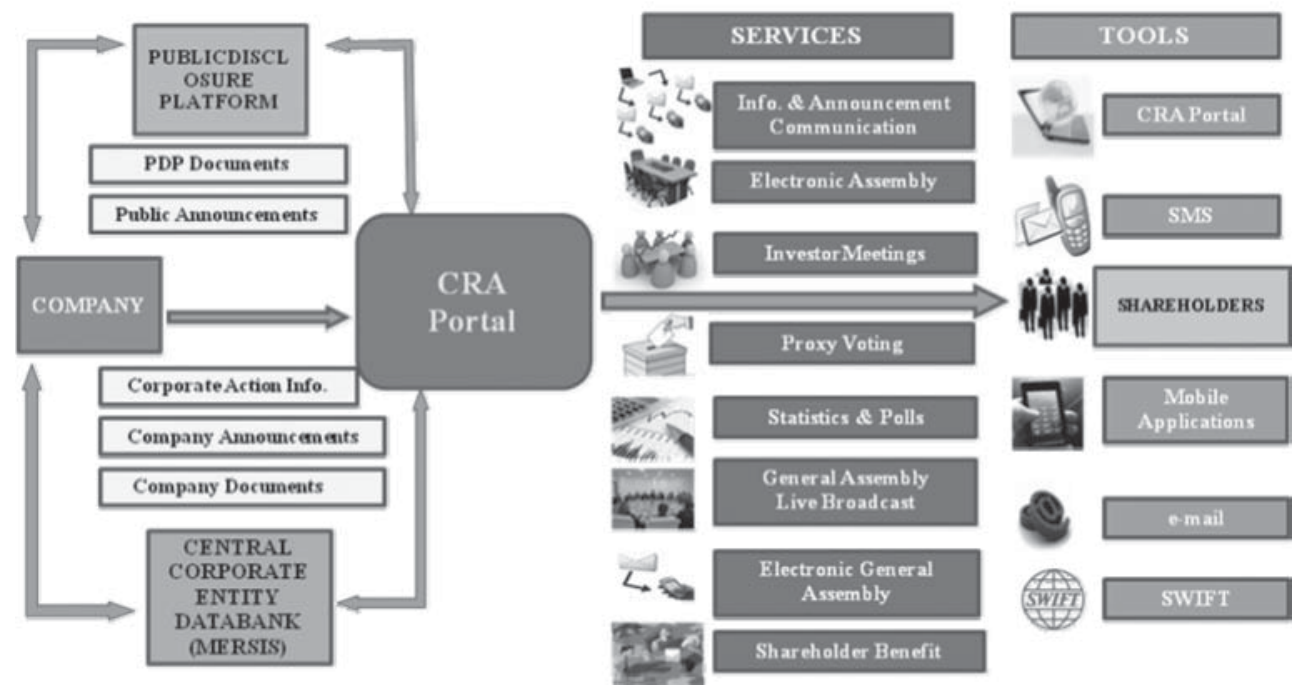

\section{THE POSSIBLE EFFECTS OF MOBILE CORPORATE GOVERNANCE MODEL PROPOSAL ON THE OECD PRINCIPLES}

It is believed that in Turkey, the CRA Mobile Corporate Governance Platform proposal would rapidly enhance the three main principles of the corporate governance put forth by OECD. Before all else, these are the principles of "The Rights of Shareholders and Key Ownership Functions," "The Equitable Treatment of Shareholder," and "Disclosure and Transparency" (Gürbüz and Ergincan, 2004). More importantly, it is possible to assert that the proposed model would give rise to a review of the definition of the corporate governance with internet and mobile communication based technologies; in this sense it would be an example for other countries.

\section{Effects Regarding the Principle of Rights of Shareholders and Key Ownership Functions}

In the light of the statements made above, it is believed that the Mobile Corporate Governance proposal would enhance the efficiency of the principles of the corporate governance significantly. Most of the progress that might emerge concerns the subject of the rights of shareholders and key ownership functions.

It is believed that, in this context, pursuant to corporate governance, protection and execution of shareholders rights would be facilitated. Thus, the main shareholders rights such as securing methods of ownership registration, conveyance or transferring shares, obtaining relevant and material information on the company in a timely and regular basis, and participation and voting in general assembly meetings would be protected efficiently. On the other hand, shareholders would be able to participate in and to be sufficiently informed on decisions concerning fundamental corporate changes, amendments to the statutes or articles of incorporation or similar governing documents of the company, 
and the authorization of additional shares and extraordinary transactions including the transfer of all or substantially all assets that in effect result in the sale of the company.

Most importantly, along with the initiation of the application of the electronic general assembly meeting process, shareholders would be able to have the opportunity to participate effectively and vote in the general assembly meetings and be informed of the rules including voting procedures that govern the general assembly meetings. In case our proposal is applied efficiently, on the one hand, shareholders would be furnished with sufficient and timely information concerning the date, location and agenda of the general assembly meetings as well as full and timely information regarding the issues to be decided at the meeting. On the other hand, shareholders would have the opportunity to ask questions easily of the board, including questions related to the annual external audit, to place items on the agenda of general assembly meetings, to propose resolutions, and to be subject to reasonable limitations.

Through providing efficient participation in the important corporate governance decisions such as the election of the board members, shareholders would be able to submit their opinions regarding the remunerations which would be paid to the board of directors and key managers. The opportunities that our proposal offers would contribute to shareholders being able to vote in person or in absentia, and would give equal effect to votes whether cast in person or in absentia. The role of the principle of transparency would ensure that the disclosure of capital structures and arrangements that enable certain shareholders to obtain a degree of control disproportionate to their equity ownership would moreover allow for corporate control of the market to function in an efficient and transparent manner.

Through the application of our proposal, it is believed that the exercise of ownership rights by all shareholders including institutional investors should be facilitated. In this context, there would be progress regarding the emphasized points in the principles of OECD such as disclosure of all institutional investors acting in a fiduciary capacity, and corporate governance and voting policies with respect to their investments including the procedures that they have in place for deciding on the use of their voting rights. Furthermore, especially through the general assembly meetings, shareholders including institutional shareholders would be allowed to consult with each other on issues concerning their basic shareholder rights.

\section{Effects Regarding the Equitable Treatment of Shareholders}

It is believed that the Mobile Corporate Governance proposal would make contributions to the subject of the equitable treatment of shareholders as well. Assurance of the equitable treatment of all shareholders including minority and foreign shareholders within the corporate governance framework would increase. Within the context of the contributions of the platform arising relevant to the subject of the treatment to all shareholders of the same series of a class equally, all investors would be able to obtain information about the rights attached to all series and classes of shares before they purchase them; likewise any changes in voting rights would easily be subject to approval by those classes of shares which are negatively affected.

It is believed that, because transparency enhances the rights of the minority shareholders, these would be protected efficiently. Also, since proxy procedure regarding the voting in the general assembly 
meeting would be more practical, votes would be used more efficiently by custodians or nominees in a manner agreed upon by the beneficial owner of the shares.

Through the changes regarding the general assembly meetings that our proposal provides, impediments to cross border voting would be eliminated, processes and procedures for general assembly meetings would allow for equitable treatment of all shareholders. It would also make it difficult to implement vote casting procedures that are already unduly difficult or expensive for companies.

\section{Effects Regarding the Principle of Disclosure and Transparency}

The benefits of this Mobile Corporate Governance proposal that provide the principle of the disclosure and transparency, one of the basic OECD principles of the corporate governance, are another important issue.

The proposed platform ensures making a timely and accurate disclosure on all matters regarding the corporation including the financial situation, performance, ownership and the governance of the company. In this regard, shareholders would easily access the information such as the financial and operating results of the company objectives. After the platform is put in place, follow-up opportunities regarding major share ownership and voting rights by the shareholders would be enhanced as well as many benefits directly relevant to the principle of transparency regarding the board of directors. Shareholders would easily access information such as the remuneration policy for members of the board and key managers, information about board members including their qualifications, the selection process, and other company directorships whether or not they are regarded as independent by the board.

The contributions provided by the platform regarding the principle of disclosure and transparency would not be limited to the cases mentioned above. It would be subject to the submission of material information by the companies such as related party transactions, foreseeable risk factors and issues regarding employees and other stakeholders, governance structures and policies, and in particular, the content of any corporate governance code or policy and the process by which it is implemented.

For the reason that shareholders would easily access matters such as preparation and disclosure of former and actual financial statements in accordance with high quality standards of accounting, financial and non-financial disclosure, all companies would be enhanced by virtue of the platform comparability. At the same time, the platform would function as a channel for disseminating the information that would result in equal, timely and cost efficient access to relevant information by users, not only for investors to fulfill their responsibilities, but also for board members to access to accurate, relevant and timely information.

\section{GENERAL EVALUATION AND CONCLUSION}

Corporate Governance, in addition to the conventional structure that includes the component and intention of profiting from the activities of joint stock companies and distributing profit to shareholders, is a concept that aims to protect the rights of all beneficial owners including shareholders and to regulate the rules of the communication between related benefiting groups. 
Like the rest of the world, the possibilities of direct communication between companies and shareholders are currently limited in Turkey. The source of information is multiple and the companies deliver the same information to several parties but cannot always reach their target investors. Nearly every country in the world is limited in forming a Primary Source of Information and providing information distribution from a single source. Companies and investors cannot reach all the information they need. Companies cannot reach all their shareholders and investors cannot reach all the issuers. There is no standard method used in company-investor relationship, and companies cannot simultaneously distribute any information to their investors. The information that is shared and the information sharing formats are not standard and internationally recognized standards are not used. Companies and investors have to bare high costs in order to reach each other.

Mobile Corporate Governance is the process of permanent communication and information sharing between companies and shareholders through the internet, electronic communication and mobile applications that meet the requirements of the principles of corporate governance more rapidly and efficiently without physical limitations. It provides broadly based and direct participation of shareholders in the corporate management and decision making processes of a corporation and leads to a higher degree of corporate democracy.

Mobile Corporate Governance is the process that begins with real-time transmission of any announcement of a corporation to all of its shareholders wherever they are through the electronic communication and mobile applications and is concluded by providing governance of the corporation on electronic platforms including electronic general assembly meetings through continuously taking advice/approvals of its shareholders on specific issues by tools such as electronic voting. This process has the promise of enhancing the corporate democracy which will lead to more participation of shareholders in company management.

Corporate governance insufficiency is one of the main problems for the Turkish capital markets. When the current technology is implemented through the CRA portal to be established by CRA, it is believed that the communication will be provided more rapidly between all the market participants, the members and the investors together. Beyond being a central securities depository, it is assumed that structuring CRA as a corporate governance and investor relations platform will enhance the social and economic benefits of capital markets in Turkey and will lead to decreasing the average cost of capital for companies. Structuring CRA as a corporate governance and investor relations platform will also help companies to increase their financing possibilities. Furthermore, it will improve the compliance level of the Turkish capital markets with the investment feasibility criteria of domestic and foreign investors.

It is envisaged that our Mobile Corporate Governance proposal might be a model for other central securities depositories with direct account holding systems that hold actual shareholder information. If our proposal is applied, the main principles of corporate governance, before all else "The Rights of Shareholders and Key Ownership Functions," "The Equitable Treatment of Shareholder," and "Disclosure and Transparency," will be rapidly enhanced. 


\section{NOTES}

1. "Investor over-optimism" means that investors are able to provide capital without envisaging taking it back in case they like the project.

2. "Reputation compulsion of the investors" entails not abandoning honesty at the cost of income resources which would be obtained in the future.

3. Corporate Governance Quotient is a rating system used to help assess the skills of company governance and executive practices by investors on the basis of performance (Brown and Caylor, 2004b).

4. In this paper any kind of mobile phones, PDAs and tablet PCs are defined as communication media.

5. On the other hand, with the establishment of the Turkish Ministry of Industry and Trade's "Central Corporate Entity Databank" (MERSIS), a future integration between MERSIS and CRA systems would minimize cases of erroneous investor ID assignments for legal persons.

6. The system application is the first of its kind among all CSDs in the world.

7. In this paper, SMS and e-mail messages are defined as electronic communication applications.

8. In this study, the term "mobile application" is used as the general expression for special software for mobile phones, PDAs and tablet PCs.

9. At present, information sharing and communication can be provided everywhere through portable computers and mobile communication tools via mobile internet access. The process that covers the adaptation of this technology to corporate governance briefly is called as "Mobile Corporate Governance".

10. The related process is cited at (Gürbüz and Ergincan, 2004).

11. The theoretical framework of Mobile Corporate Governance and its effects on corporate democracy will be discussed in another study by the author.

12. Media portals and social network sites such as Facebook and Twitter are placed in the second group since the users of them provide one-to-many information sharing. In this case, the information is suitable for common usage.

13. In accordance with article 1524 of the Turkish Commercial Code Number 6102, which has already been approved by Grand National Assembly of Turkey, to become effective on 01.07.2012, equity companies are obliged to have a web site.

14. About the inclusion of the PDP to the process, see (Gürbüz and Ergincan, 2004). 
15. The ISE has launched a service about the transmission of the PDP announcements through SMS to investors. It is believed that after our suggestions are implemented, it would be more appropriate to offer this service through the Mobile Corporate Governance Platform.

16. About the functions that CRA could undertake, see (Gürbüz and Ergincan, 2004).

17. In particular, after the establishment and implementation of technical and legal infrastructure of registered e-mail addresses, sending e-mail only to the registered ones that are legally defined would be required.

18. It is asserted that it has been estimated that voting on the Internet costs US $\$ 0.03$ per shareholder, while the postage cost involved in the traditional proxy voting raises the cost to US $\$ 0.37$. See (Alcock et. al., 2006).

19. In US, a rule was put into effect by the SEC, ordering that transmission of the single proxy declaration to shareholders sharing the same address would be sufficient. It is expressed that this rule can be applied to persons sharing the same electronic mail address. See (Freidman, 2002).

20. "The Act on Registered Shares to Ease the Execution of Voting Rights" (NaStraG), adopted on 21 January 2001 in Germany, eases the execution of voting rights through proxy. This act ensures benefit from any of the communication instruments for the appointment act of a person determined as proxy of the voting right by the company. As such, it is possible to appoint this person through fax and e-mail. Moreover, a shareholder depositing his shares in a bank or an equivalence agency would appoint a proxy through electronic forms provided on an internet platform. However, a revision is required in the articles of association for this. See (Bilgili, 2004; Bilge, 2003).

21. Article 1027 of the Turkish Commercial Code Number 1602 provides the means for companies to organize electronic general assembly meetings. In this context, attendance at as well as submission of a proposal and voting in the electronic general assembly meeting have the same effect and result in the same actions in the physical meeting.

22. For point of views corresponding the functions that CRA can take in hand. See (Gürbüz and Ergincan, 2004).

23. Since the Electronic General Assembly and the functions that CRA can take in hand will be discussed in another paper by the author, information is provided in brief.

24. The Danish Central Depository Agency after the change in the Danish Code of Commerce in 2003 implemented the first electronic general assembly practice in April 2009 by using software of a Sri Lankan software company. Furthermore, the same institution began offering the services of investor-oriented transmission of information and announcement, proxy voting and representation, statistics, polls and reporting which are among our Corporate Governance platform recommendations. 


\section{REFERENCES}

Alcock, R., Daly, A., Conde C., and Robinson, A.A. (2006). Electronic Proxy Voting in Australia. Allens Arthur Robinson Publications.

Asian Pacific Economic Corporation Forum, (2003).

Balioğlu, D. (2000). “Anonim Ortaklıklarda Karşılıklı İştirak,” Sermaye Piyasası Kurulu Yeterlilik Etüdü.

Bauen, M. and Venturi, S. (2009). Swiss Board of Directors. Zürich: Schulthess Verlag.

Bilge, M.E. (2003). “Anonim Ortaklık Genel Kurul Toplantılarında Temsilci Aracılı̆̆ıyla Oy Vermede İnternetin Kullanımı,” Atatürk Üniversitesi Erzincan Hukuk Fakültesi Dergisi, 7(1/2): 341-367.

Bilgili, F. (2004).“İnternet ve Anonim Ortaklık Genel Kurul Toplantıs1,” Prof. Dr. Necip Kocayusufpaşaoğlu İçin Armağan: 565-588. Ankara.

Brown, J.R. (1996). "Securities Law Implications of the Internet,"Available [on line] at: www.law. du.edu/jbrown/internet/interne1.htm

Brown, L.D. and Caylor, M.L. (2004a). "Corporate Governance and Firm Performance," Available [on line] at: www.papers.ssrn.com/sol3/papers.cfm?abstract_id=586423

------, (2004b). "The Correlation between Corporate Governance and Company Performance, Corporate Governance Study, Institutional Shareholder Services,” Available [on line] at: www.tkyd.org/files/downloads/corporate_governance_study_104.pdf

Capital Markets Board of Turkey, (2003). Corporate Governance Principles Guide.

Central Registry Agency, "Rules and Principles of Operations and Informatics," Available [on line] at: http://www.mkk.com.tr/wps/portal/MKKEN/DocumentLibrary/GuideBooks /!ut/p/b1/04_SjzS0MDE0tbA014_Qj8pLLMtMTyzJzM9LzAHxo8zivVx8v R3dTE0MDELdjAw8ff09QkKCAgwN3E30vfSj0nPyk4BKw_WjwIoNcAB HA30_j_zcVP3cKNe8ckdFRQD2pbdq/d14/d5/L2dJQSEvUUt3QS80SmtFL 1o2X0pETUtBRjU0MDBEOUEwSU1POUxEUEIxR0cw

-----, (2010). CRAweb Investor Operating Guidebook. Available [on line] at:www.mkk.com.tr/wps/ $\mathrm{wcm} /$ connect/3ba6ee88-df72-47b2-ab49-74dfe54340aa/MKKweb.pdf?MOD=AJPERES

Clark, G. (2000). "Pension Funds and Corporate Governance: An Anglo-American Perspective," University of Oxford, Working Paper in Employment, Work, and Finance WPG-0018, October.

Clarke, T. (2007). International Corporate Governance: A Comparative Approach. UK: Abingdon. 
Çeker, M. (1995). "Halka Açık Anonim Şirketlerde Temsilci Aracılığıyla Oy Kullanma ve Pay Sahiplerine Çağrıda Bulunarak Vekalet Toplanması,” Banka ve Ticaret Hukuku Dergisi, 18(1/2): 173-197.

Çetiner, E. and Erol, M. (2007). "Kurumsal Yönetim ve Kurumsal Yönetimin Aile Şirketlerinde Uygulama Düzeyinin Belirlenmesine Yönelik Ampirik Bir Çalışma," Muhasebe ve Denetime Bakış, 6(21). Available [on line] at: www.turmob.org.tr

Doğu, M. (2003). “Kurumsal Yönetim Düzenlemeleri,” SPK Meslek Personeli Derneği Dergisi, August: 1-19.

Ergincan, Y. (2005a). "Hisse Senetlerinin Kaydileştirilmesi: Dünya ve Türkiye Uygulaması," Geleneksel Finans Seтроzуити, 2004, Uluslararas1 Piyasalarda Finansal Entegrasyon, 1(178), May, Istanbul.

------, (2005b). "Protecting Investors and Lessening Moral Hazard in Capital Markets by Using Mobile Communications and Internet Technologies and the Role of Central Registry Agency of Turkey," Journal of Economic and Social Research, 7(1): 31-50.

Freidman, H.M. (2002). "Frequently Asked Questions about Company Web Sites and the Federal Securities Law," Rocky Mountain Securities Conference, May.

Gürbüz, O. and Ergincan, Y. (2004). Kurumsal Yönetim: Türkiye’deki Durumu ve Geliştirilmesine Yönelik Öneriler. İstanbul: Literatür Yayıncılık.

Hansmann, H. and Kraakman, R. (2000).“The End of History for Corporate Law,” New York University Working Paper, January.

Harm, C. (2000). “The Limits of Corporate Governance - An Examination of Manager-Shareholder Problem," Available [on line] at:

www.wiwi.uni-muenster.de/iw/downloads/ch/Manager-Shareholder\%20Conflict.pdf

ISE, Public Disclosure Platform. Available [on line] at: www.ise.org/PublicDisclosurePlatform/ PublicDisclosurePlatform.aspx?sfopl=true

Kayıhan, Ş. (2003). “Anonim Ortaklıklarda Genel Kurul ve İnternet,” Banka ve Ticaret Hukuku Dergisi, 22(1): 79-109.

Kleinschmidt, M. (2007). Venture Capital, Corporate Governance, and Firm Value. Germany: Wiesbaden.

La Porta, R., Lopez-de-Silanez, F., Shleifer A., and Vishny R. (1999). "Investor Protection: Origins, Consequences, Reform," Financial Sector Discussion Paper, No.1, The World Bank, September.

Leech, D. (2002). "Shareholders Voting Power and Ownership Control of Companies," Warwick Research Paper, No.564. 
Lloyd-Jones, R. (2010). "Control, Conflict and Concession: Corporate Governance Accounting and Accountability at Birmingham Small Arms 1906-1933." Accounting Historians Journal. Available [on line] at: www.findarticles.com/p/articles/mi_qa3657/is_200506/ai_n1468246

Magdi, I. (1999). “Corporate Governance-Framework for Implementation,” World Bank Working Paper.

Mcafee, A. (2006). "Enterprise 2.0: The Dawn of Emergent Collaboration," MIT Sloan Management Review, 47(3): 21-28.

Merkezi Kayıt Kuruluşu, "Yatırımcı Hizmetleri," Available [on line] at: www.mkk.com.tr/MkkComTr/tr/yatirimci/hizmetler.jsp;jsessionid=4B7337A571EAFDA21BF7F0C EB69A419C

Mietzner, M. (2009). "Changes in Corporate Governance and Corporate Valuation, DIRK Forschungsreihe," Band 13.

Millstein, I.M. (1998). Corporate Governance-Improving Competitiveness and Access to Capital in Global Markets. OECD Publishments, Paris.

Ministry of Industry and Trade, (2010). "2010 Performance Programme." Available [on line] at: http://www.sanayi.gov.tr/Default.aspx?lng=en

Morck, R. and Nakamura, M. (1999). Japanese Corporate Governance and Macroeconomic Problems. Harvard University.

OECD, (1998). Corporate Governance Principles.

------, (2004). Corporate Governance Principles.

Shleifer, A. and Vishny, R.A. (1994). "Survey on Corporate Governance," National Bureau of Economic Research Working Paper, No. 5554.

Tekinalp, Ü. (2000). Nama Yazılı Kaydi Payların Devrinde Merkezi Kayıt Kuruluşunun Kayıtlarının Etkisi ve Niteliği. İstanbul: Seçkin Yayıncılık.

Tekinay, N.A. (2006).“Uzman Görüşü: Robert Worcester ile Röportaj,” Capital: Aylık Isss ve Ekonomi Dergisi, 14(2): 58-60.

The Official Gazette (Resmi Gazete), (1956). “Turkish Commercial Code Number 6762,” 09.07.1956, No: 9353.

------, (1981). “Capital Markets Law, No: 2499,” 30.07.1981, No: 17416.

------, (1993). “The Capital Markets Board's Communiqué on Principles Governing Public Disclosure of Material Circumstances,” 06.07.1993, No: 21629. 
------, (1994). “The Capital Markets Board's Communiqué On Principles Regarding Proxy Voting at Shareholders' Meetings of Public Joint Stock Companies, Proxy Solicitation and Tender Offer," 09.04.1994, No: 21872.

------, (1996). "The Regulation Regarding General Assembly Meeting of the Equity Companies and Commissar of Industry and Commercial Ministry Attending to these Meetings,” 07.08.1996, No: 22720.

------, (1998). “The Capital Markets Board's Communiqué on Principles Regarding Registration with the Capital Markets Board and Sale of Shares," 15.11.1998, No: 23524.

------, (2000). “The Capital Markets Board's Communiqué on Principles Regarding Intermediary Activities and Intermediary Institutions," 07.09.2000, No: 24163.

------, (2001). "The Regulation Concerning Incorporation, Operation and Supervision of The Central Registry Agency,” 06.21.2001 (Issue No: 24439)

------, (2002). “The Capital Markets Board's Communiqué on Principles Regarding Book Entry Recording of Dematerialized Capital Market Instruments,”22.12.2002, No: 24971.

------, (2003a). "The Capital Markets Board's Communiqué on Principles Regarding Cumulative Voting at Shareholders Meetings of Joint Stock Companies Subject to Capital Market Law," 18.02.2003, Issue No: 25024.

-----, (2003b). “The Capital Markets Board's Communiqué on Principles Regarding Ratings and Rating Agencies," 04.12.2003, No: 25306.

Turkish Commercial Code, (2011). Number 6102 (The Date of Approval by Grand National Assembly of Turkey: 13.01.2011)

Tuzcu, M.A. (2005). “IMKB-100 Şirketlerinin Kurumsal Yönetim Anlayış1,” Aktaş R. ve başk. (eds.), Dördüncü Orta Anadolu Issletmecilik Kongresi Bildiri Kitabı, TOBB ETÜ, Ankara.

VP, “The World's First 100\% Virtual AGM was Recently Held in Denmark," Available [on line] at: www.virtualgeneralmeeting.com/C12574CC002D6735/0/F961F426FB2A8589C125759F0028D8B4

------, "VirtualGeneralMeeting FactSheet,”Available[online] at:www.uk.vp.dk/C1256CF30038E736/ sysOakFil/Fact\%20sheet\%20-\%20VGM/\$File/vp.VGM.pdf

Zetzsche, D.A. (2005). “Corporate Governance in Cyberspace - A Blueprint for Virtual Shareholder Meetings," CBC-RPS No. 0011. Available [on line] at: www.ssrn.com/abstract=747347 